\title{
Blurring the Line between Licit and Illicit: Transnational Corruption Networks in Central Asia and Beyond
}

\author{
Alexander Cooley \\ J.C. Sharman \\ Barnard College, Columbia University \\ Griffith University
}

ac210@columbia.edu and j.sharman@griffith.edu.au

\section{PLEASE PROVIDE ABSTRACT}

\begin{abstract}
The anti-corruption norm in both scholarship and the policy world has too narrowly focused on the domestic and institutional context of bribe-taking and public corruption. Instead, we argue that corruption in the contemporary global economy requires a multiple set of connected transactions, processes and relationships that take place within informal transnational networks that blur the line between illegal and legal activities. These networks include multinational companies, elites in host countries, offshore financial vehicles and conduits, middlemen and brokers, and destination financial institutions. We examine how these actors operate in Central Asia, a region that is widely identified as corrupt, yet is rarely understood as embedded in the types of global processes, offshore connections and transnational links specified in our analysis. Examples of offshore centers in tax planning from Central Asia, and partial results from a field experiment based on impersonating high corruption risks from four Central Asian states, provide evidence for how the various actors in transnational financial networks structure their dealings. We then present two brief illustrative cases of how these transnational networks have operated in energy explorations services in Kazakhstan and telecommunications contracts in Uzbekistan. Our findings have theoretical, practical, and normative implications for scholars and practitioners of Central Asian international political economy and other "high risk" regions.
\end{abstract}




\section{Introduction}

A recent annual ranking of international billionaires by Forbes magazine included a short article dedicated to Central Asia. The magazine observed that, 'In Central Asia, the fortunes of the region's billionaires are directly tied to the progression (or not) of national economies as well as closely integrated to national politics' (Forbes, March 25, 2013). The article confirms what is now a conventional wisdom about the region's governing elites: that many of Central Asia’s wealthiest have used their domestic political standing for private economic advantage.

This much is well known and appears relatively uncontroversial to observers of the region's patronage politics. It is also consistent with current international perceptions of the region as presented in the rankings and reports of anti-corruption monitors such as the Berlin-based Transparency International. Such judgments follow the rise of the socalled international "transparency regime," the attempt to combat public corruption and prohibit the taking of bribes as a clear standard of international ethical business behavior. The regime itself has empowered citizens, advocacy groups and the media to try to more clearly identify instances of corruption, quantify and measure it, and even compare its prevalence across countries. Yet because of empirical limits to our knowledge about corruption, the regime's overall effectiveness is essentially unknown. Cases like those discussed in this paper, however, raise considerable doubt as to whether corruption has in fact been reduced.

But if Central Asia is so corrupt and challenging as an investment environment, how can we explain why multinational companies and states continue to regularly 
transact with the region in "high risk" sectors? Given the contradictory strictures of the international transparency regime versus the local pressure for bribes and kick-backs, how do foreign actors negotiate these conflicting demands? What, if anything, might the increasing use of offshore vehicles to conduct commercial transactions tell us about the more hidden transnational links that undergird deal making in the region? And to what extent should Multinational Companies (MNCs), their home states and international organizations be held accountable for acts of domestic bribery that may occur in these “risky” environments?

Using Central Asia as an empirical referent, we argue that the evolution of the anti-corruption norm in both scholarship and the policy world has too narrowly focused on the domestic and institutional context of bribe-taking and public corruption. Instead, we argue that corruption in the contemporary global economy requires a multiple set of connected transactions, processes and relationships that take place within transnational networks, rather than isolated instances that occur exclusively within national boundaries. These transnational networks, and the broader point that corruption is increasingly a transnational phenomenon, are the central focus of the article. Also critical is the notion that while the legal system draws a sharp line between criminal and lawful activities, the evidence presented here suggests more of a continuum between licit and illicit activities. The outright looting by senior public officials is enabled by and woven into broader structures of the global economy, including commodity and financial markets, shell companies and other corporate vehicles, and international banking networks. Further, in making these claims, we wish to demonstrate how the offshore and onshore realms are tightly linked, and how each is the site of a particular set of activities and practices that 
are important to the network as a whole. The failure to fully appreciate the transnational nature of much serious corruption, and the tendency whereby such behavior shades into and is mingled with licit markets and institutions onshore and off, compromises the effectiveness of the global anti-corruption regime and excessively narrows our understanding of governance.

Like other transnational networks in international politics, transnational corruption networks are characterized by a variety of different types of actors including multinational companies, elites in host countries, offshore financial vehicles and conduits, middlemen and brokers, and destination financial institutions. Unlike other transnational networks, such as human rights advocacy, the actors within these illicit networks shun publicity, as their different elements refuse to acknowledge the illicit nature of some of their activities, or even their exact relations to other parts of the network. Clearly, this secrecy greatly complicates the study of such networks, and means that the findings presented here can only be tentative.

We begin by reviewing the literature on the anti-corruption norm and the transparency regime, and then present our own account of the constitutive elements of transnational corruption networks. We then examine how these actors operate in Central Asia, a region that is widely identified as corrupt, yet is rarely understood as being embedded in the types of global processes, offshore connections and transnational links specified in our analysis. Examples of offshore centers in tax planning from Central Asia, and partial results from a field experiment based on impersonating high corruption risks from four Central Asian republics, provide evidence for how the various actors in transnational financial networks structure their dealings. We also present two brief 
illustrative cases of how these transnational networks have operated across different sectors and countries in the regions: energy explorations services in Kazakhstan and telecommunications contracts in Uzbekistan. We conclude with some suggestions for extending this research agenda for both those interested in corruption, and scholars of Central Asian international political economy.

\section{The Practice and Theory of the Anti-Corruption Norm}

\section{Practicing the Anti-Corruption Norm}

Corruption is most commonly defined as the misuse or the abuse of public office for private gain. The term describes an incredibly wide range of activities, from petty cash bribes for minor administrative services, trading in influence and nepotism, and spectacular instances of embezzlement leading to the loss of hundreds of millions of dollars (Rose-Ackerman 1999). Though perhaps the full range of corrupt practices exists in Central Asia, the practices and policy responses most relevant to this paper relate to bribery in international business transactions, and kleptocracy, as our case studies demonstrate. Both these types of corruption constitute the kind of transnational corruption networks we discuss later.

The global anti-corruption norm arose in the 1990s, in seeming lock step with the acceleration of globalization. Though corruption as a topic was not new, the propensity to judge it as a harmful global phenomenon and as an issue worthy of external monitoring of states seems to rapidly have taken hold in international public life shortly after the collapse of the Soviet Union (Wang and Rosenau 2001, 25).

The rise of the accompanying 'good governance' regime involved a number of 
new and long-standing actors. Transparency International (TI) is the world's most visible and influential watchdog, and has played a leading role in publicizing and institutionalizing the norm. Since its founding in 1995, TI impressively positioned itself as the leading global anti-corruption watchdog by publishing the highly visible Corruption Perceptions Index (CPI), an evaluation and ranking of states according to their perceived levels of corruption and bribe-taking. Established international financial actors, particularly the World Bank but also later the International Monetary Fund, started to present corruption as a significant domestic barrier to economic development and successful growth under the rubric of the 'good governance' agenda. Though the first moves to discuss the previously taboo topic of corruption came in connection with World Bank work on Africa at the end of the 1980s, the Bank and others took a much more public and forthright stance from the mid-1990s (Weaver 2008, Chapt. 4; Bukovansky 2006; Abbot and Snidal 2002).

The norm was then quickly institutionalized in a number of formal regional agreements and international treaties, including the Council of Europe's Criminal Law Convention on Corruption (1999), the OECD’s Anti-Bribery Convention (1997), and the Inter-American Convention against Corruption (1996). Relating to hydrocarbon and other resources more specifically, in 2002-2003 a group of NGOs and governments supported by the World Bank launched the Extractive Industries Transparency Initiative, aimed at certifying public disclosure of contracts and payments in this realm to counter the problem of the 'resource curse.' The United Nations Convention Against Corruption (UNCAC), agreed in 2003, was the first comprehensive global treaty (signed by over 165 
countries) that prohibited different forms of corruption and established mechanisms for international monitoring and cooperation in the anti-corruption effort.

The bribery of government officials by foreign firms was one aspect of corruption that galvanized the earliest international co-ordination, especially in the form of the 1997 OECD Convention. The agreement committed signatories to criminalizing the bribery of foreign officials by either individuals or corporations from signatory states. Bolstering international agreements like the OECD and UN conventions are increasingly tough national enforcement actions against firms engaged in corruption abroad. Previously, not only was bribing foreign officials allowed by many OECD countries, but in many countries it was actually tax deductible, and even after the Convention was signed often little was done to implement its provisions (Warner 2007).

The obvious exception is the United States, which in 1977 passed the Foreign Corrupt Practices Act. Not only has the enforcement of this Act become more rigorous over time, the United States has also claimed wider jurisdiction, for example including foreign firms listed on US stock markets, or even just those that transact in US dollars. Following the embarrassment of the BAE-Saudi Arabian arms bribery scandal, the UK government passed strong anti-bribery legislation in 2010 that also had extra-territorial effect, and introduced criminal liability for firms that fail to promote an anti-corruption culture.

More recently in the policy spotlight is kleptocracy (literally 'rule by thieves'), which has come to refer to large-scale corruption perpetrated by leaders and their families. Such 'grand corruption' may or may not include bribery by foreign firms, but the laundering of the proceeds almost always has an international aspect. Though the 
chase for the money of ousted President Ferdinand Marcos after his flight from the Philippines in 1986 is an early example, recovering kleptocrats' assets has become an international priority only over the last decade or so (Kim and Sharman 2014). At the insistence of developing countries, the UNCAC included a whole chapter on this issue. In a move that received widespread media and policy attention, in 2004 TI released a list of the top 10 kleptocrats (reproduced later in this paper; Transparency International 2004). In 2007 the World Bank and United Nations joined forces to set up the Stolen Assets Recovery (StAR) Initiative, a program combining research with technical assistance (World Bank/UNODC 2007). Finally, the Arab Spring revelations concerning the scale of corruption among the leaders of Tunisia, Libya and Egypt prompted the G20 to also lend its substantial political weight to the policy problem of chasing dictators' loot. With each new initiative, the emphasis has progressively shifted from the kleptocrats themselves, to the countries that host their looted assets.

\section{Theorizing the Anti-Corruption Norm}

In the academy, a few scholars have questioned the selective assumptions of the new anti-corruption norm and the propensity to measure it and compare countries (Abbot and Snidal 2002; Bukovansky 2006; de Sousa et al. 2009; and Knack 2007). However, many more appear to have taken advantage of these new corruption measures, indicators and indices to explore the factors associated with varying levels of corruption as both an explanatory factor and outcome. To take just two examples, Sanholtz and Gray (2003) have argued that greater international integration, particularly links with international organizations, is likely to decrease a state's levels of corruption, while D'Souza (2012) finds evidence that the OECD’s Anti-Bribery Convention has altered trading patterns 
among countries from high risk to lower risk. Though these are important findings, they reproduce the ontology of the anti-corruption norm that views the phenomenon as contained within states and the illicit practices of their public officials. When corruption is studied in its transnational context, it is usually as part of the sensationalist study of illicit networks that seek to link international criminals and terrorists with illicit activities (Naim 2006).

Yet, as authors such as Mick Moore, Peter Andreas and Kelly Greenhill remind us (Moore 2012; Andreas 2011; Andreas and Greenhill 2010), the study of illicit political economy all too often draws unwarranted differences between the legal and illegal sectors, and overstates or simply invents data for political purposes. We illustrate something of this dynamic with sections on gradations of the licit uses of offshore financial centers and the illicit uses of onshore centers. Furthermore, the literature on transnational crime usually fails to consider the very central role of the state and its agents in maintaining and even benefiting from these categories. Indeed, by studying issues such as money laundering, offshore finance and corruption as part of the 'illicit' domain, we may miss the more subtle ways in which a whole transnational architecture of actors and processes also help to facilitate nominally legal transactions. Similarly, ignoring the growing global dimension of money-laundering leaves a large theoretical hole in our understanding of how business and investment actually take place in the contemporary global economy, as we illustrate with examples of various legal and illegal financial practices below.

The Uses of Offshore and Onshore Financial Centers: What is Legal, What is Illicit? 
The rise of the offshore world has spawned some attention in the IPE literature, yet its import to the global economy is still underappreciated and undertheorized (Palan et. al. 2010). The conventional wisdom often has it that the flows of money to tropical island offshore tax havens are by definition dirty money, while those going to established centers like London and the U.S. are by definition clean. But, as we will explore, much of the funds going to tax havens may be legal and, conversely, capital flowing to OECD centers may be the proceeds of crime (Chaikin and Sharman 2009). The continuum between licit and illicit flows is further illustrated by examples of commonly practiced offshore tax planning.

A 2010 PriceWaterhouseCoopers commentary on changes to Kazakhstan's tax code observed that among the most relevant offshore jurisdictions for the country are the UK Overseas Territory of the British Virgin Islands (BVI) and Cyprus (Bregonje and Bezborodov 2010). The former jurisdiction is the default option for those seeking offshore shell companies and has a zero tax rate. The latter has particularly close relations with the former Soviet states, in considerable part because Cyprus has a double-tax treaty with the USSR that still applies to all the former republics bar Russia, Ukraine and Kyrgyzstan, which are covered by subsequent bilateral treaties (Cyprus Double Tax Treaties, 2007). Cyprus has a 10\% corporate tax rate, but also a wide range of tax treaties with 50 other countries that can be used in tax planning.

One example relates to a Russian company (Yiolitis 2012), but thanks to the tax treaties a similar logic applies to all the Central Asian states too. An individual holds a major shareholding in a group of manufacturing companies worth \$500 million that she wishes to sell as a package. She creates a Cypriot holding company with three resident 
directors who hold a management meeting on the island. The Central Asian investor then swaps the $\$ 500$ million of shares with a new issuance of (worthless) shares in the holding company, leaving the latter in possession of the valuable shares without any sale having taken place according to the EU Mergers Directive, thus avoiding a \$1 million stamp duty charge. Now the Central Asian investor owns the holding company, which in turn owns the $\$ 500$ million stake in the manufacturing companies. Profits from manufacturing can be sent to the holding company at a special concessionary 5\% rate levied by the Central Asian authorities (as opposed to the standard rate of $20 \%$ corporate income tax in, for instance, Kazakhstan), and tax-free in Cyprus, thanks to the tax treaty. Because Cyprus does not tax dividend payments, the individual can then receive these payments from the holding company tax-free. The individual then sells $30 \%$ of the shares in the holding company via a BVI company to a seller, realizing a $\$ 50$ million capital gain on the $\$ 150$ million sale. Because there is no tax on capital gains in Cyprus (apart from property), and no tax at all in BVI, the sale is again tax-free.

A similar dynamic may obtain for money flowing into the Central Asian states also. In this case Central Asian firms selling with the EU would do so through a Cypriot holding company that would own subsidiaries in each relevant EU country. Profits would flow back to the Cypriot holding company tax-free. As noted above, Cyprus does not levy taxes on dividends or capital gains, and other corporate profits are taxed at only $10 \%$. The money can then be returned to the home country without further taxes, as the tax treaty states that this income has already been taxed in Cyprus. The Cypriot banking crisis did not affect this kind of structure, as the Cypriot companies involved would typically hold their accounts in another European country. 
Of course, critics may object that this kind of tax minimization might be legal, but it is nevertheless unethical. This kind of debate over the legitimacy of such aggressive tax planning helps to illustrate the basic point about the inadequacy of assuming that a sharp line can been drawn to separate licit from illicit finance, and the utility of thinking of these concepts as opposite ends of a spectrum. Rather than Cyprus being some sort of rogue or pariah jurisdiction in the tax opportunities it provides, other EU members like Ireland, Malta, Latvia, Denmark, Belgium and especially the Netherlands offer similar facilities to Cyprus, while major onshore companies like Google, Apple and almost all international pharmaceutical companies energetically exploit such schemes. Tax planning is the preserve neither of tropical islands nor of corruption-prone Central Asian states, but is standard practice onshore and off. These examples also serve to demonstrate that what might be thought of as a purely national economic concern, for example, a manufacturing enterprise in Kazakhstan with all of its employees, sales and managers in that country, is instead legally, financially and fiscally a transnational enterprise spread between Central Asia, the Eastern Mediterranean and the Caribbean.

\section{Bearer Share Companies}

Another point that undermines the notion of a simple dichotomy between licit and illicit finance is the fact that some onshore centers have aspects of their regulatory regime that are definitely beyond the pale. We consider systematic experimental data in support of this claim later, but one particular example is the issue of UK bearer share warrant companies. Bearer share companies are defined as such because whoever holds the physical share certificates owns the company, there is no central registry of ownership. 
As such, it is almost impossible for investigators to determine the company's owner, a feature that has been singled out as creating a major money laundering vulnerability.

Bearer shares have been abolished or immobilized (i.e., they must be held at a specified fixed address known to the authorities) in almost all recognized tax havens. Britain, however, continues to offer unrestricted bearer share companies, despite David Cameron making the transparency of company ownership a top priority in $2013 .{ }^{1}$ To prove the point, co-author Sharman took delivery of a UK bearer share shell company from a UK firm in 2013 purchased over the internet for \$700 using a corporate credit card (drawn on Griffith University). The resulting legal person, Owens Saint Amans Ltd (UK), has a Ukrainian nominee director who has provided Sharman with a signed but undated letter of resignation, and a Power of Attorney agreement under which the director acts only on Sharman's instructions. The legal owner of the company is whoever holds the one A4 sheet of paper that represents the $£ 1$ share certificate. The case of Kyrgyz Asia Universal Bank illustrates the critical importance of these British corporate vehicles, in that UK shell companies were instrumental in the transfer of $\$ 700$ million of alleged criminal proceeds connected with the Bakiyev regime. In one case the ostensible Russian owner of the British company had died two years before the company was

\footnotetext{
${ }^{1}$ Section 779 of the 2006 UK Companies Act reads:

(1) A company limited by shares may, if so authorised by its articles, issue with respect to any fully paid shares a warrant (a "share warrant") stating that the bearer of the warrant is entitled to the shares specified in it.

(2) A share warrant issued under the company's common seal or (in the case of a company registered in Scotland) subscribed in accordance with the Requirements of Writing (Scotland) Act 1995 (с. 7) entitles the bearer to the shares specified in it and the shares may be transferred by delivery of the warrant.

(3) A company that issues a share warrant may, if so authorised by its articles, provide (by coupons or otherwise) for the payment of the future dividends on the shares included in the warrant.
} 
formed (Global Witness 2012). The point is not just that one cannot assume that offshore finance is by definition illicit while onshore finance is licit, especially when both kinds of centers are intimately linked and co-dependent within the same networks, but rather that distinguishing licit from illicit finance in the first place is extremely difficult.

\section{Corrupt Transactions as Informal Transnational Networks}

Given the number of interested actors, institutions and complex processes involved in the business dealings that involve the corruption of private officials, we suggest that corruption is better studied as a transnational network. In the study of international relations, the transnational network concept has been usefully applied to study the impact and role of non-state actors in world politics such as the rise of transnational activists and NGOs (Keck and Sikkink 1998), criminal organizations and the operation of terrorists (Eilstrup-Sangiovanni and Jones 2008).

In the case of transnational corruption networks, we argue that the dual principles linking members of the network are profit and covertness. The latter is particularly important, because it shapes the way actors regard and present their role in any given transaction, structures the contracting and subcontracting business, leads to layering and the use of offshore vehicles to conceal the origins and nature of related transactions, and encourages actors to deny that they are members of the network or actually connected to each other in more systematic ways. Individually, the elements of transnational corruption networks include:

1. Domestic Elites: The government officials and elites who control access to state assets and resources, award contracts and licenses, and seek private pay-offs for granting access. 
2. International Actors: International actors who seek access or state contracts, including multinational companies; security actors such as foreign militaries and private security actors; and defense contractors.

3. Brokers: The middlemen (consultants, lawyers, advisors) who structure the deal and mediate between the interests of international actors and local elites.

4. Offshore Vehicles and Conduits: Offshore vehicles and conduits help to facilitate side-payments to elites, they conceal the national origins of investments, they create legal entities that may not be subject to national regulations governing reporting, disclosure and taxation.

5. Destination Havens: These are the final destinations for transaction-related pay-offs and laundered moneys. Though elites need offshore vehicles to conceal the origins and identity of their financial transfers, they will usually seek dependable and reputable banks and financial institutions in major onshore financial centers for their gains, as well as property holdings and conspicuous consumption (World Bank/UNODC 2009).

Transnational Networks: Greater than the Sum of their Parts?

Beyond the narrow functions of these individual constitutive elements of these transaction networks, the network as a whole helps to facilitate side-payments to elites without visibly flouting bribery laws or international anti-corruption norms, while sufficiently disguising the transaction as a whole so as to provide 'plausible deniability'” to both the countries and companies that seek access and the government elites who control it (Cooley 2012, 134-38). 
Once more blurring the simple binary between licit and illicit practices, secreting assets may serve to protect against the attentions of predatory states (after all, paranoids have enemies too). Most Central Asian governments head predatory states with little regard for the rule of law or the elementary human rights of their citizens. Given these circumstances, it is unsurprising that wealthy individuals would seek to safeguard assets by hiding them out of reach of their governments. Along the lines of Mikhail Khodorkovsky, even individuals guilty of tax or financial offences may be targeted as part of a political vendetta rather than for these crimes as such.

Transnational transaction networks, especially in procurement, extractive industries and telecommunications, should not just be viewed as sites for structuring complex deals, but are themselves shaped indirectly by the very nature of the anticorruption norm and its international enforcement. The contours of the informal network are necessarily dynamic: as the international anti-corruption norm expands to demand more due diligence of companies in dealing with third parties or with local vendors, and enforcing agencies push the boundaries of enforcement, transactional networks must refashion and modify themselves to circumvent new rules, monitoring standards and enforcement procedures. Analytically, if we take as a constant that multinational companies will seek to expand market access, on the one hand, and that, on the other, elites in areas such as Central Asia will continue their rent-seeking behaviors, then transnational networks must adapt in response to changing anti-corruption practices and increased international oversight. As foreshadowed earlier, this suggests Western complicity and even active involvement in many of the corrupt activities usually thought of as exclusively the result of domestic actions. This claim is borne out with evidence 
from a field experiment where the authors impersonated (among others) corrupt officials from Kyrgyzstan, Tajikistan, Turkmenistan and Uzbekistan later on in the paper (Findley, Nielson and Sharman 2014).

\section{Mapping Central Asia's Transnational Corruption Networks}

The Central Asian region provides a particularly instructive group of cases for analyzing transnational corruption networks, precisely because they are often viewed as secluded, isolated from world markets and even autarkic. Some draw distinctions between the resource-rich economies of Turkmenistan, Kazakhstan and even Uzbekistan and the impoverished and smaller states of Kyrgyzstan and Tajikistan, both significant recipients of international assistance since their independence. Others differentiate the Central Asian economies according to their relative formal integration into the global economy, with Kazakhstan the clear regional leader in terms of financial integration and Kyrgyzstan a WTO member, and the more closed Uzbekistan and Turkmenistan on the other end.

Most basic data about informal barriers to trade identify Central Asia as one of the most trade-unfriendly regions in the world, with import and export times considerably higher than areas such as Africa, the Middle East and Latin America (Cooley 2012, 15456). Indeed, Western policymakers have even talked of the need to establish a new regional economic strategy they term the "New Silk Route" to ignite commerce and regional economic integration in order to foster cooperation and strengthen economic ties with Afghanistan. By contrast, our case studies of Central Asia's transnational corruption networks suggest that the region, at least at the elite level, remains selectively highly 
integrated within the global economy. Using the special legal designations and opportunities afforded by offshore financial vehicles, Central Asian elites have embedded their illicit activities within new transactional networks that have concealed their dealings, while allowing external suitors the access they have sought.

\section{Measures of Central Asian Corruption and Kleptocracy}

International bureaucrats and Western officials usually single out corruption as the most important barrier to greater economic integration. The World Bank's Global Governance indicators place four out of the five Central Asian states in the bottom 10 percentile, while Kazakhstan ranks in the bottom $20^{\text {th }}$. These estimates are consistently corroborated by their similarly low rankings in TI’s Corruption Perceptions Index, which in 2013, out of a total of 174 evaluated states, ranked Kazakhstan 140th, Kyrgyzstan 150th, Tajikistan 154th, and Turkmenistan and Uzbekistan joint $168^{\text {th }}$. Similarly, most investor guides and political risk analyses rank Central Asia poorly and warn of the politically uncertain political and legal environment that foreign investors face. Despite these warnings, foreign companies regularly bid and compete for rights to the region's extractive sectors, infrastructure projects and telecommunications networks, suggesting that the investor risk represented by some of these indicators perhaps does not fully capture the procedures and practices necessary to guarantee investments in the region.

Economically, all of the Central Asian states are predatory kleptocracies, where governing elites systematically appropriate the states' most lucrative assets and use them for their private profit. The origins of the region's severe rent-seeking are debated: some point to the legacy of the Soviet system which encouraged patrimonialism and informal 
activity (Crtichlow 1988), especially at the republican and regional levels, while others identify the introduction of new market reforms as providing the necessary enabling conditions (McMann 2009).

Whatever the propensities for rent-seeking left by the Soviet system, a casual examination of the fortunes amassed by rulers, their families and loyalists, reveals a clear connection between Central Asia's authoritarian political regimes, access to state resources and assets, and their private enrichment during the independence period. Examples abound: President Niyazov of Turkmenistan is alleged to have amassed over $\$ 3$ billion in an account at DeutcheBank before it was frozen following his death (Global Witness 2006). The Karimov family fortune, spread over President Islam Karimov and his daughter Gulnara Karimova, has been founded on a range of government-related businesses; in 2010 a German magazine (Der Spiegel, March 1, 2010) estimated Karimova's personal fortune alone at \$570 million. Imomali Rahmon, 20-year leader of Tajikistan, according to Radio Free Europe-Radio Liberty (October 2, 2013), has accumulated 'hundreds of millions' from an economic empire, which, according to leaked US Embassy cables, includes his unofficial control of state aluminum revenues and hydroelectric enterprises (The Guardian December 12, 2010). And in Kyrgyzstan, both Presidents Akayev and Bakiyev amassed large fortunes during their time in office, gaining cuts of insider privatization deals, foreign aid, mining contracts and, it appears, contracts related to the US base at Manas airports (Toktomushev 2014, this volume).

Kazakhstan is the richest and most financially integrated of the Central Asian states and, according to Forbes magazine (March 25, 2013), it also boasts 5 billionaires. They include President Nazarbayev’s son-in law Timur Kulibaev (net worth $\$ 1.3$ billion) 
and his second daughter Dinara Kulibaeva (\$1.3 billion), while the President's first daughter Dariga Nazarbayeva is the $13^{\text {th }}$ wealthiest person in Kazakhstan (net worth $\$ 593$ million), with her 27-year old son boasting a fortune of \$200 million (Eurasianet March 11, 2012). 
Table 1: TI Top 10 Kleptocrats versus Central Asian Rulers, Alleged Loot

\begin{tabular}{|c|c|c|c|}
\hline Kleptocrat (Country) & Estimated Loot & $\begin{array}{l}\text { Central Asian Elite or } \\
\text { Ruling Family Member }\end{array}$ & Estimated Loot \\
\hline $\begin{array}{ll}\begin{array}{l}\text { Mohamed } \\
\text { (Indonesia) }\end{array} & \text { Suharto } \\
\end{array}$ & $\$ 15-35$ billion & $\begin{array}{l}\text { Saparmurat Niyazov } \\
\text { (Turkmenistan) }\end{array}$ & $\$ 3$ billion (a) \\
\hline $\begin{array}{l}\text { Ferdinand Marcos (the } \\
\text { Philippines) }\end{array}$ & $\$ 5-10$ billion & $\begin{array}{ll}\begin{array}{l}\text { Gulnara } \\
\text { (Uzbekistan) }\end{array} & \text { Karimova } \\
\end{array}$ & $\$ 570$ million (b) \\
\hline $\begin{array}{l}\begin{array}{l}\text { Mobutu Sese } \\
\text { (Zaire) }\end{array} \\
\end{array}$ & $\$ 5$ billion & $\begin{array}{l}\text { Timur Kulibaev } \\
\text { (Kazakhstan) }\end{array}$ & $\$ 1.7$ billion (c) \\
\hline Sani Abacha (Nigeria) & $\$ 2-5$ billion & $\begin{array}{ll}\text { Dinara } & \text { Kulibaeva } \\
\text { (Kazakhstan) } & \end{array}$ & $\$ 1.7$ billion (c) \\
\hline $\begin{array}{l}\text { Slobadan Milosevic } \\
\text { (Yugoslav/Serbia) }\end{array}$ & $\$ 1$ billion & $\begin{array}{l}\text { Dariga Nazarbayeva } \\
\text { (Kazakhstan) }\end{array}$ & $\$ 593$ million (d) \\
\hline $\begin{array}{l}\text { Jean-Claude Duvalier } \\
\text { (Haiti) }\end{array}$ & $\$ 300-800$ million & $\begin{array}{ll}\text { Imomali } & \text { Rahmon } \\
\text { (Tajikistan) } & \\
\end{array}$ & Hundreds of millions (e) \\
\hline Alberto Fujimori (Peru) & $\$ 600$ million & $\begin{array}{l}\text { Nurali Nazabayev } \\
\text { (Kazakhstan) }\end{array}$ & $\$ 200$ million (d) \\
\hline $\begin{array}{ll}\text { Pavlo } & \text { Lazarenko } \\
\text { (Ukraine) } & \\
\end{array}$ & \$114-200 million & & \\
\hline $\begin{array}{ll}\text { Arnoldo } & \text { Aleman } \\
\text { (Nicaragua) } & \\
\end{array}$ & $\$ 100$ million & & \\
\hline $\begin{array}{l}\text { Joseph Estrada (the } \\
\text { Philippines) }\end{array}$ & \$78-80 million & & \\
\hline
\end{tabular}

Sources:
a. Global Witness 2006.
b. Der Spiegel 1 March 2010.
c. Forbes, accessed 21 November 2014.
d. Forbes Kazakhstan, as quoted in Eurasianet 11 May 2012.
e. $R F L / R E 2$ October 2013.

Generally overlooked in these news accounts, is that none of these fortunes could have been amassed and stored without sustained contacts with international markets, companies, financial vehicles and dependable destination banks to house these gains.

\section{Central Asia and the Offshore World}

Perhaps the most striking aspect of Central Asia's global economic interactions has been its rapid integration into the offshore world. Consider the similar experiences of Kazakhstan and Tajikistan, usually regarded, respectively, as the region's most globalized and sophisticated economy and its most impoverished and isolated. 
Kazakhstan's burgeoning ties to the offshore world were facilitated in 2003 when the Kazakh central bank approved a list of new offshore zones for banking, insurance, pension funds and securities operations, including a group of recognized tax havens ('Kazakhstan regulations: Offshore financial zones approved,' EIU Viewswire April 1, 2003). As Table 2 suggests, offshore jurisdictions have become an integral part of conducting both outward and inward commercial transactions. Most strikingly, in 2012 the Netherlands was the largest source of inward investment (42\%) and outward investment (58\%) to and from Kazakhstan, totals which seem to owe less to the actual interest of Dutch companies in Central Asia, and more to the small European country's current positions as the global leader in hosting intermediate holdings and conduit vehicles. According to one account, in 2009 over 1,600 billion Euro worth of Foreign Direct Investment (FDI), about 16\% of global stock, was diverted via the Netherlands (Weyzig 2012).

Somewhat incredibly, the British Virgin Islands ranks as Kazakhstan's $4^{\text {th }}$ largest source of FDI and $3^{\text {rd }}$ largest investment destination, ahead of Russia on both counts. In October 2012 the head of Kazakhstan’s Tax Commission Anuar Dzhumadildayev told a meeting of Finance Ministry officials that 737 Kazakh companies are registered in the British Virgin Islands in order to launder money, noting that 86 of these companies had merged into one in the Karaganda province (Central Asia Newswire October 31, 2012). Scholars suggest that the BVI are themselves a leading source of FDI to China and destinations of Chinese FDI abroad, suggesting that a good proportion of these offshore flows to Central Asia may actually originate in China (Sharman 2012; Vlcek 2010, 11214). Overall, Henry James of the Tax Justice Network, an NGO that tracks capital flight 
and offshore transactions, estimates that Kazakhstan's total unaccounted for capital flows, since independence, are over \$109 billion (Henry 2012, Appendix III, 34).

Table 2: Origins of Foreign Investment Kazakhstan 2011

\begin{tabular}{|c|c|c|c|c|c|}
\hline \multicolumn{5}{|c|}{ Kazakhstan: Direct Investment from/in Counterpart Economy Data } & \\
\hline \multicolumn{5}{|c|}{ From Top Five Sources/To Top Five Destinations (US Dollars, Millions) } & \\
\hline \multicolumn{2}{|c|}{ Inward Direct Investment } & \multicolumn{3}{|c|}{ Outward Direct Investment } & \\
\hline Total Inward & 94,843 & $100 \%$ & Total Outward & 19,481 & $100 \%$ \\
\hline Netherlands & 40,247 & $42 \%$ & Netherlands & 11,274 & $58 \%$ \\
\hline United States & 14,655 & $15 \%$ & United Kingdom & 4,050 & $21 \%$ \\
\hline France & 7,479 & $8 \%$ & Virgin Islands, British & 707 & $4 \%$ \\
\hline Virgin Islands, British & 4,167 & $4 \%$ & Russian Federation & 611 & $3 \%$ \\
\hline China, P.R.: Mainland & 3,862 & $4 \%$ & United States & 599 & $3 \%$ \\
\hline
\end{tabular}

Source: IMF Coordinated Investment Survey. http://cdis.imf.org

Similar patterns of offshore transactions and the splitting of legal entities can be seen in Tajikistan, the poorest of the Central Asian countries and arguably the least formally integrated in global economic trade. Though Tajikistan offers no similar detailed data of origin of inward and outward investments, a number of sources suggest the growing importance of offshore vehicles, especially BVI-registered entities. In 2012 Tax Justice Network estimated that offshore transfers from Tajikistan reached \$2.3 billion, while the IMF in a report in November 2012 estimated that the total reached as high as \$3.5 billion, about half of the country’s 2011 official GDP (RFE January 22, 2013).

Most notably, the Tajikistan Aluminum Company (TALCO), Tajikistan’s largest enterprise and source of export revenues with reported ties to the ruling family, has used a web of offshore registries to conduct and hide its dealings (Heathershaw 2011); in one set of court proceedings bought forth in the controlling legal domain of the BVI, TALCO alleges that a former manager conspired with the Russian Rusal, the world's largest 
aluminum company, to divert over \$500 million in profits between 1996 and 2004 and stash them in offshore bank accounts (Financial Times, November 28, 2008). Commenting on speculations about capital flight and the use of offshore vehicles, the head of the National Bank Tajikistan admitted, "It's possible that funds are transferred from Tajikistan to Britain, Germany, Russia and other countries and then from those places to offshore regions. For this reason, it is difficult to determine the amount of funds that go to offshore regions” (BBC January 22, 2013).

It seems that hiding both the origin and ultimate definition of these flows is one of the primary reasons behind the use of offshore vehicles. In energy deals, the use of intermediary and holding companies to structure acquisitions and payments is now commonplace. For example, an investigation of the structure of Turkmenistan-Russia fuel deals by the NGO Global Witness (2006) found that much of the graft and kickbacks was channeled through Itera, an intermediary trading company that for many years exclusively handled Turkmenistan’s gas exports to Ukraine. The same company allegedly gifted Turkmenistan's new President a 60 million euro luxury yacht (The Guardian, December 2, 2010).

One of the most extreme examples of this type of camouflaging was the fate of deposits in Kyrgyzstan's largest bank Asia Universal Bank in the waning days of President Kurmanbek Bakiyev’s rule. After Bakiyev’s ouster in April 2010, the bank was found to have been insolvent, with up to $\$ 240$ million having been withdrawn from the bank in the days prior to the government's collapse. A comprehensive investigation of its transactions by the watchdog Global Witness found significant evidence of money laundering through the bank, as dozens of companies, registered onshore and offshore, 
moved hundreds of millions of dollars through the bank without any clear business activity or purpose (Global Witness 2012). According to the report, $\$ 1.2$ billion passed through just three UK companies with no clear business dealings, while a number of the transactions were also routed through major Western banks including Citibank in New York, Standard Charter in London, and Austria’s Raiffaisen Zentralbank. These episodes and our own case studies support the conclusion in the more general literature that shell companies are a vital component of transnational corruption networks, and that such companies function to obscure key actors behind a corporate veil (World Bank/UNODC 2011).

The Rise of the Brokers

Aside from foreign providers of shell companies, the brokering role also appears to have been played by a number of foreign businessmen, lawyers and advisors in the region. Brokers typically have acted as agents of Central Asian elites, negotiated contracts on their behalf and, most importantly, helped to structure the side-payments, terms and sequencing of deals that have been informally demanded of international companies seeking primary contracts.

The most notorious broker operating in the region was the American James Giffen, who in the early 1990s became a close advisor and gatekeeper to President Nursultan Nazarbayev of Kazakhstan. Giffen organized introductions to international energy companies, brokered large deals, and acted as a fixer for the ruling family during the first years of independence, eventually earning himself a Kazakh diplomatic passport (LeVine 2007). He reportedly structured at least six large international oil deals involving 
American companies that included Texaco, Amoco, Philips Petroleum, and Mobil Oil (Hersh 2001, 51). Giffen and his company allegedly took cuts of successful transactions, while the broker allegedly used a complex network of over 30 offshore bank accounts and shell companies to direct unlawful payments from these oil companies to the personal Swiss bank accounts of 'very senior’ Kazakh officials (Hersh 2001, 51; LeVine 2007; and Newsweek July 24, 2000). In 2003, he was arrested at New York's John F. Kennedy airport and indicted for wire and mail fraud, money laundering, and violations of the Foreign Corrupt Practices Act (FCPA). In 2010, after a lengthy delay in court proceedings that mostly focused on the defendant's right to introduce classified material to show that he was operating in cooperation with major US government agencies and intelligence services, Giffen pled guilty to one violation of the FCPA and was sentenced to time already served, while the Judge in the case thanked him for his service to US geopolitical interests (Bloomberg, December 16, 2010).

Though Giffen was the quintessential broker, similar roles are now played, though perhaps not with the same public persona, by groups of lawyers and accountants who are skilled in both negotiating contracts and structuring their terms. Particularly notable in the last two decades is the entry of prominent Western law firms who have opened offices in the region, as well as the increasing tendency of local lawyers to have U.S. or British law qualifications, or at least take a temporary placement at a firm in one of these two countries. In Kazakhstan foreign law firms include Baker \& McKenzie (Chicago), Bracewell \& Giuliani (Houston), Cadbourne \& Parke (New York), Curtis, MalletPrevost, Colt \& Mosle (New York), Denton Wilde Sapte (London), Dewey \& LeBoeuf (New York), MacLeod Dixon (Calgary), McGuire Woods (Richmond), Salans (Paris) 
and White \& Case (New York), as well as the big four accounting firms. Comparative literature on kleptocracy suggests that unscrupulous lawyers are commonly a key node in the transnational laundering networks (U.S Senate 2006, 2010; World Bank/UNODC 2011).

Central Asia's Transnational Corruption Networks and the Weakness of International Rules: Evidence from a Field Experiment

But what of international rules and regimes designed to counter such activities? After all, international standards mandate that those firms forming and selling shell companies must collect identity documents from the real owner, so that investigators can "look through" the corporate veil to find the owner should the need arise. This requirement is especially important where there is a high corruption risk, as indicated by the customer's country of origin and the particular business sector.

Findley, Nielson and Sharman (2014) based a field experiment around impersonating high-corruption risk customers from four Central Asian republics and soliciting offers for shell companies via email to determine what identity documents were required (if any), i.e. whether it was possible to obtain an untraceable shell company in contravention of international anti-money laundering rules. The email approach is as follows (along with the nationality of the client, the bolded text differentiates this email from the "control” email discussed below):

Dear [Provider]:

I have a consultancy firm which I operate in Kyrgyzstan with some colleagues where we reside. We have multiple clients in different countries. We focus specifically on public-sector consulting for government procurement. Since some of our outside business is in your area, we were hoping to see some saving 
on our tax by setting up an international corporation. Also, our business has been growing of late and we would like to reduce unforeseen liabilities. We would like to form a new company in your area as private individuals. We were wondering if you could provide us with some more information. Specifically, we are very interested in keeping the process of setting up this company as confidential as possible. That said, what are the kinds of identifying documentation would you require of us as we set this up? Also, how much do you usually charge for these services? I will be travelling extensively over the next period and will prefer to communicate via email.

Warm regards, Kylych Almas

The logic of this experiment was that this email 'treatment' was randomly assigned to firms along with a 'control' (or placebo) email from a low corruption-risk customer (hailing from one of eight OECD countries ranked among the least corrupt in the world by TI’s Corruption Perceptions Index). Along with the high corruption risk country of origin, corruption risk is also signaled by the Central Asians' mention of being involved in government procurement, a notoriously corrupt sector. The combination of a high corruption risk country, high corruption risk sector, the mention of consultancy (a common alibi for corruption), and the explicit request for confidentiality jointly constitute an obvious prompt to the provider that the client very likely wants the company to launder illicitly acquired funds. Because of random assignment, and the large number of solicitations (1930 control emails and 480 corruption treatments) we can be confident that any difference between the compliance rates for the two types of approach emails is caused by the different risk profile (see Gerber and Green 2012).

The experiment provides two kinds of information. First, a diagnostic test of how effective the international rules mandating identity documents collected from those forming shell companies actually are in practice. Second, whether those selling shell companies have any sensitivity to corruption risk among customers in applying the rules. 
The results are aggregated in a Dodgy Shopping Count, which measures on average how many providers a potential client would have to approach before finding one willing to supply a shell company without requiring any official photo identity documents, in violation of international transparency standards. The higher the Dodgy Shopping Count, the harder it is to obtain an untraceable shell company, and the more rigorously the rules are being applied, and vice versa for low Dodgy Shopping Counts. The results were not encouraging.

Before presenting the quantitative data from the experiment it is worth reproducing some sample replies to illustrate the nature of the problem:

Here is the pricing and annual requirements for NV and WY ... We don't need a whole lot of info from you. You can place the order on our website under starting your company. It should only take 10 minutes and that is all the information we need from you.

We have many international clients with the same confidentiality concerns so I am happy to tell you that you have found the right service provider for your needs!

Rather than being the proverbial few rotten apples, these quotes are illustrative of a larger problem. First of all, even including those providers that did not reply at all, on average our corruption risks would have had to approach an average of only 11.5 shell company providers before finding one willing to plainly violate international rules even when faced with a blatantly obvious money laundering risk. By comparison, incredibly, low corruption risk customers were actually slightly less likely to be offered an untraceable shell company (Dodgy Shopping Count 11.3), completely undermining the risk-based approach that is supposed to govern due diligence in this area. 
Parsing the results by the 182 countries of origin of the providers included in the experiment also led to highly counter-intuitive results. Looking at the overall results, providers in recognized tax havens proved to be much more compliant with international corporate transparency standards when dealing with solicitations for high-risk Central Asian clients than OECD countries. Indeed, even developing countries proved to be better at enforcing global standards on shell companies than OECD states.

These worrying results provide stark evidence of why large-scale corruption and kleptocracy are so prevalent in Central Asia despite formal international rules to the contrary; they also underscore the important role of OECD countries in facilitating the laundering the proceeds within transnational corruption networks.

\section{Central Asia’s Informal Corruptions Networks: Two Illustrative Cases}

In our limited remaining space, we illustrate the constitutive elements and proposed dynamics of these transnational networks by presenting brief case sketches involving oil deals in Kazakhstan and telecommunications licensing in Uzbekistan. However, the logic of our argument should be broadly applicable to almost any corruption scandal in the region that has implicated a foreign entity seeking to secure access to Central Asian deals. Indeed, as Toktomushev (this volume) and Cooley (2012) show, the lucrative fuel contracts for the US air base at Manas appear to have been routed through offshore entities and murky legal vehicles in order to hide their ties to Kyrgyz elites.

Case \#1: Oil Deals in Kazakhstan: Baker Hughes 
Our first case involves the business dealings of Baker Hughes, an oil services company based in Texas that bribed Kazakh officials in an effort to win a \$219 million oil services contract in Kazakhstan in 2000. According to the complaint filed by the SEC, Baker Hughes Services International (BHSI), a wholly owned subsidiary of the Texas company in Kazakhstan, is alleged to have paid \$5.2 million to two agents knowing that the money was going to be used to bribe Kazakh officials and members of the stateowned oil company, Kazakhoil. Specifically, a Kazakhoil official involved in the award of the Karachaganak gas field deal demanded that BHSI pay a designated consultancy firm $3.0 \%$ of the value of the prospective contract's earned revenue.

Key to the deal according to the indictment was the involvement of a broker, referred to as "Agent A," who was hired as a consultant by BHSI and named as a coconspirator but not defendant. In mid-September 2000, a few weeks before the contract was awarded, Agent A approached and informed BHSI that the Kazakhoil official demanded a payment be directed to a consulting company (Company A) owned by Agent A in order for the Baker Hughes to obtain the contract. A leaked US Embassy cable later identified the consultant as Robert Kissin, a UK national, describing him as the alleged 'key middleman who handled a \$4 million secret payment.' According to a 2007 SEC press release, Baker Hughes paid the agent that sum, but 'received no identifiable services' from him (U.S. Securities and Exchange Commission, 'SEC Charges Baker Hughes With Foreign Bribery and with Violating 2001 Cease-and-Desist Order')

The broker's role centered on creating a set of financial vehicles to direct the payment and conceal its ownership, as the consulting company was registered in the Isle of Man. From May 2001 through November 2003, Baker Hughes made monthly 
payments totaling over $\$ 4$ million to the offshore company (United States vs. Baker Hughes Services International, at paragraph 14, 7). According to an investigative story, the payments were moved from the Isle of Man entity to bank accounts at Barclays in London (The Guardian December 10, 2010). Baker Hughes realized \$19.9 million in profit from the project.

In the final settlement, BHSI pled guilty to counts of violating the FCPA and aiding and abetting the falsification of the records of its parent company. BHSI agreed to pay an \$11 million criminal fine, while Baker Hughes paid \$23 million in disgorgement and prejudgment interest, as well as \$10 million for violating a previous 2001 SEC directive to cease and desist from altering records in response to FCPA concerns about its activities in Indonesia (New York Times, April 27, 2007). At the time, the total of $\$ 44$ million in fines and penalties constituted a record settlement for US FCPA cases. The company settled civil complaints regarding similar FCPA violations of record keeping in its operations in Uzbekistan, Russia, Angola and Indonesia, but the final criminal settlement covered only the company's activities in Kazakhstan.

\section{Case \#2: Telecoms in Uzbekistan}

Our second case covers the activities of the Swedish-Finnish telecommunications company Teliasonera in its dealings with Uzbekistan (part of the company's aggressive mid-2000s strategy to tap into potentially lucrative Eurasian markets), particularly allegations that it provided pay-offs to Gulnara Karimova, the daughter of the country's President Islam Karimov. Karimova has long faced allegations of using her political connections to build a commercial empire and muscle out foreign companies from 
successful businesses, but the involvement of Scandinavian company in a transnational corruption network has received considerable press coverage in the West and precipitated the resignation of its CEO Lars Nyberg in February 2013 after an internal investigation revealed a lack of due diligence in the company’s dealings with the Central Asian country (Reuters February 1, 2013).

A series of investigative reports by Swedish television news program Uppdrag Graskning found that, contrary to initial denials by Teliasonera, the company paid a total of $\$ 320$ million to the regime for licenses and access to the Uzbek market. The centerpiece was an initial \$250 million deal over licenses in spring 2007 after direct negotiations with the Karimov regime (SVT, “Teliasonera Negotiated directly with the Karimov Regime; and $R F E / R L$, May 22, 2013). The investigation showed that in September 2007 the company paid an initial \$30 million sum to a local Uzbek company called Teleson Mobile, which had been formed just 17 days earlier. Teleson was owned by the 24-year old Armenian woman Gayane Avakyan, who was also owner of Takilant Ltd., another local company that received $26 \%$ shares of the company. Takilant was registered in Gibraltar with no history, offices or assets, while Avankyan was revealed by one account to be Karimova's personal assistant and by another as the director of Karimova’s fashion company “House of Style,” based in Tashkent (Organized Crime and Reporting Project [OCCRP], 'Swedish Telecom took Shortcut in Central Asia.' December 29, 2012). Public accounting documents of Takilant made no mention of any payments or equity transfer, while CEO Nyberg himself, according to a Swedish paper, referred to the payment as an 'investment' in a company, and not a payment (The Local, September 20, 2012). 
One of the Teliasonera's whistleblowing executives subsequently confirmed the multi-step sequencing of the deal. Teliasonera officials were told that after transferring $26 \%$ of the shares in the new Uzbek company (UCell) to Karimova, the company would later buy back those shares within 2-3 years for a preset amount. Indeed, according to one report, in 2010, Teliasonera proceeded to buy $20 \%$ of the $26 \%$ shares owned by Taklilant for approximately \$220 million, increasing its ownership of the Uzbek mobile phone operator from $74 \%$ to $94 \%$ (UzDaily, February 2, 2010). In a follow-up investigation, as reported by Uznews.net, the Swedish channel found that in 2010 Teliasonera bought an unnecessary 4G license from the same Gibraltar-entry, Takilant, for $\$ 55$ million, thus taking the total value of suspected payments to regime-related entities to over $\$ 300$ million (Uznews.net, November 7, 2012).

The broker for the deal appears to have been Bekhzod Akhmedov who reportedly handled the payments even though at the time he was, remarkably, CEO of the competitor mobile company Uzdunrobita, but Karimova’s right-hand man. According to documents filed in Swedish courts, Telesonaria officials who negotiated with Akhmedov believed that he was 'the telecom representative of Gulnara Karimova' (Eurasianet March 11, 2013).

Subsequent Swiss and Swedish investigations, including money-laundering probes, were triggered when Avakyan attempted to access the Takilant 'destination accounts' that were legally controlled by Akhmedov; these accounts were frozen, pending the outcome of these investigations (Eurasianet September 12, 2012). In November 2013, four additional members of Teliasonera were dismissed following an internal review, with the company issuing the statement that, 'on the basis of the 
information and conclusions to date it is evident to Teliasonera's Board and CEO that the processes for conducting some transactions have not been in line with sound business practices’ (Eurasianet December 2, 2013).

\section{Conclusion: Central Asia's Transnational Transaction Networks}

At first glance, few regions might seem to be further removed from exotic island tax havens or the centers of high finance than the Central Asian states. In contrast, this paper has argued that these countries are in fact intimately linked with such financial centers. The initial question raised in this paper was how Western multinational companies have been able to reconcile the conflicting demands of global anti-corruption standards on the one hand, and Central Asian kleptocrats' requirements for side-payments via transnational financial networks on the other. Using various sources of evidence, from case studies, to measures of international capital flows and corruption rankings, to field experiments, we have found that in squaring the circle this relationship between foreign firms and local rulers is crucially dependent on transnational corruption networks that blur the lines between licit and illicit.

Rather than a just dyadic relationship between Central Asian elites and foreign firms, however, we see a more complex arrangement that is also reliant on the services of brokers, offshore vehicles and conduits, and destination havens as well. These parties cooperate to manage the daunting transaction costs inherent in operating in this part of the world to keep the wheels of commerce turning. However, many of the same parties are also involved in deeply corrupt practices that have seen local rulers amass spectacular fortunes at the expense of the countries they rule. Such wealth could not have been 
acquired without the support of local and Western intermediaries, offshore shell companies, and banks in major Western financial centers. In each case, the relevant actors have managed to maintain a façade of compliance with international anticorruption standards while often being passively or actively complicit in the very practices these standards seek to prevent.

These findings tend to reinforce the reservations other scholars have raised about relying on conventional wisdom and simple dichotomies in seeking to understand the illicit international political economy. Predatory states controlled by small, self-serving cliques blur the line between public and private interests. The methodologically nationalist standpoint of measuring corruption through country-by-country rankings can be deeply misleading in obscuring how official malfeasance in states that score worst in such rankings, like the Central Asian countries, is in fact intimately related to financial institutions and law firms from those countries ranked as cleanest. This conclusion raises profound questions about the effectiveness of the global transparency regime and the raft of anti-corruption agreements concluded over the last two decades, even with the shift to look beyond just bribe-givers and -takers in investigating those who facilitate grand corruption and host the resulting funds. 


\section{References}

Abbot, K. and Snidal, D. 2002. "Values and Interests: Legalization and the Fight Against Corruption,” Journal of Legal Studies 31 (1): 141-178.

Andreas, P. 2011. "Illicit Globalization: Myths, Misconceptions, and Historical Lessons." Political Science Quarterly 126 (3): 403-425

Andreas, P. and Greenhill, K. eds. 2010. Sex, Drugs, and Body Counts: The Politics of Numbers in Global Crime and Conflict. Ithaca: Cornell University Press.

Bregonje, R. and Bezborodov, S. 2010. “The Battle Against Tax Havens Rages in Kazakhstan... and Treaty Partners are Victimized,” Intertax 38 (2): 118-127.

Bukovansky, M. 2006. “The Hollowness of Anti-Corruption Discourse,” Review of International Political Economy 13 (2): 181-209.

Chaikin, D. and Sharman, J.C. 2009. Corruption and Money Laundering: A Symbiotic Relationship. New York: Palgrave.

Cooley, A. 2012. Great Games, Local Rules: The New Great Power Contest in Central Asia. Oxford: Oxford University Press.

Critchlow, J. 1988. "'Corruption', nationalism, and the native elites in soviet central Asia." The Journal of Communist Studies and Transition Politics 4 (2): 142-161.

Eilstrup-Sangiovanni, M. and Jones, C. "Assessing the Dangers of Illicit Networks: Why Al-Qaida may be less Threatening than Many Think." International Security 33. (2): 744.

Findley, M.G., Nielson, D.L. and Sharman J.C. 2014. Global Shell Games: Experiments in Transnational Relations. Cambridge: Cambridge University Press.

Gerber, A. S. and Green, D.P. 2012. Field Experiments: Design, Analysis, and Implementation. New York: W.W. Norton.

Global Witness. 2012. Grave Secrecy: How a Dead Man can Own a UK Company and other Hair-Raising Stories from Kyrgyzstan and Beyond. London.

Global Witness. 2006. “It’s a Gas- Funny Business in the Turkmen-Ukraine Gas Trade.” London and Washington D.C.

Heathershaw, J. 2011. "Tajikistan Amidst Globalization: State Failure or State Transformation?” Central Asian Survey 30 (1): 147-168.

Henry, J. H. 2012. The Price of Offshore Revisited. Tax Justice Network. 
Hersh, S. 2001. “The Price of Oil: What was Mobil up to in Kazakhstan and Russia?” The New Yorker, July 9, 2001.

Keck, M. and Sikkink, K. 1998. Activists Beyond Borders: Advocacy Networks in International Politics. Ithaca, NY: Cornell University Press.

Kim, H.J. and Sharman J.C. 2014. “Accounts and Accountability: Corruption, Human Rights, and Individual Accountability Norms.” International Organization 68: 2.

Knack, S. 2007. "Measuring Corruption: A Critique of Indicators in Eastern Europe and Central Asia." Journal of Public Policy 27 (3): 255-291.

LeVine, S. 2007. The Oil and the Glory: the Pursuit of Empire and Fortune on the Caspian Sea. New York: Random House, 2007.

McMann, K. 2009. "Market Reform as a Stimulus to Particularistic Politics.” Comparative Political Studies, 42 (7): 971-994.

Moore, M. 2012. “The Practical Political Economy of Illicit Financial Flows.” In Draining Development? Controlling Flows of Illicit Funds from Developing Countries edited by Peter Reuter. Washington D.C.: World Bank, pp.457-482.

Palan, R., Murphy, R. and Chavagneux, C. 2010. Tax Havens: How Globalization Really Works. Ithaca: Cornell University Press.

Rose-Ackerman, S. 1999. Corruption and Government: Causes, consequences, and reform. New York: Cambridge University Press.

Sandholtz, W. and Gray, M.M. 2003. "International Integration and National Corruption." International Organization 57 (4): 761-800.

Sharman, J.C. 2012. “Chinese Capital Flows and Offshore Centers,” Pacific Review, 25 (1):17-33.

de Sousa, L., Larmour, P. and Hindess, B., eds. 2009. Governments, NGOs and AntiCorruption: The New Integrity Warriors. London: Routledge.

D'Souza, A. 2012. "The OECD Anti-Bribery Convention: Changing the Currents of Trade." Journal of Development Economics 97 (1): 73-87

Transparency International, 2004. Global Corruption Report: Political Corruption. Berlin. 
United States Securities and Exchange Commission. 2007. "SEC Charges Baker Hughes With Foreign Bribery and with Violating 2001 Cease-and-Desist Order.' April 26, 2007: http://www.sec.gov/news/press/2007/2007-77.htm

United States Senate. 2006. Tax Haven Abuses: The Enablers, the Tools and Secrecy. Washington D.C.: Permanent Subcommittee on Investigations.

United States Senate. 2010. Keeping Foreign Corruption out of the U.S.: Four Case Histories. Washington D.C.: Permanent Subcommittee on Investigations.

Vlcek, W. 2010. "Byways and Highways of Direct Investment: China and the Offshore World,” Journal of Chinese Current Affairs 39 (4), 111-142.

Wang, H. and Rosenau, J.N. 2001. "Transparency International and Corruption as an Issue of Global Governance." Global Governance 7 (1): 25-49.

Warner, C.M. 2007. The Best System Money can Buy: Corruption in the European Union. Ithaca: Cornell University Press, 2007

Weaver, C.E. 2008. Hypocrisy Trap: The World Bank and the Poverty of Reform. Princeton: Princeton University Press, 2008.

Weyzig, F. 2009. "Tax Treaty Shopping: Structural Determinants of Foreign Direct Investment Routed through the Netherlands." International Tax and Public Finance (2012): 1-28

World Bank and United Nations Office for Drugs and Crime. 2007. Stolen Asset Recovery (StAR) Initiative: Challenges, Opportunities and Action Plan. Washington D.C.

World Bank and United Nations Office on Drugs and Crime. 2009. Stolen Asset Recovery: Politically Exposed Persons: A Policy Paper on Strengthening Preventative Measures. Washington D.C.

World Bank and United Nations Office on Drugs and Crime. 2011. The Puppet Masters: How the Corrupt Use Legal Structures to Hide their Stolen Assets and What to do About It. Washington D.C.

Yiolitis, E. 2012. “Russia-Cyprus: Case Study on Project M,” International Financial Centres Review: Invest Cyprus. 